\title{
Sport for All in Indonesia: A Review of Sport Development Concept
}

\author{
Endi Rustandi ${ }^{1, *}$, Adang Suherman ${ }^{2}$, Amung Ma'mun $^{2}$, Rudi $^{1}$ \\ ${ }^{1}$ Physical Education Study Program, Universitas Majalengka, Majalengka, Indonesia \\ ${ }^{2}$ Sport Education, School of Postgraduate Studies, Universitas Pendidikan Indonesia, Bandung, Indonesia
}

Received April 23, 2021; Revised July 12, 2021; Accepted July 22, 2021

\section{Cite This Paper in the following Citation Styles}

(a): [1] Endi Rustandi, Adang Suherman, Amung Ma'mun, Rudi, "Sport for All in Indonesia: A Review of Sport Development Concept," International Journal of Human Movement and Sports Sciences, Vol. 9, No. 4A, pp. 130 - 135, 2021. DOI: 10.13189/saj.2021.091322.

(b): Endi Rustandi, Adang Suherman, Amung Ma'mun, Rudi (2021). Sport for All in Indonesia: A Review of Sport Development Concept. International Journal of Human Movement and Sports Sciences, 9(4A), 130 - 135. DOI: 10.13189/saj.2021.091322.

Copyright $\bigcirc 2021$ by authors, all rights reserved. Authors agree that this article remains permanently open access under the terms of the Creative Commons Attribution License 4.0 International License

\begin{abstract}
Background: The development of appropriate and comprehensive sports for all levels of society is essential in every regional development step in sports. Various approaches have been made to study the development of sports, but the primary system is sport development and development through sport. At the same time, both systems relate to facilitating sport participation. Methods: The method used was a systematic literature review (SLR). The literature search was limited to articles published from 2012-2019 in the research database, including in Elsevier and Taylor and France online. Result: This review provides a comprehensive and systematic view of sport for all and sport development from previous research to assess community participation through several sport programs to create a healthy active lifestyle. Conclusion: This review shows a shift in the concept paradigm from sport development to Sport for Development. Sport is not only to create a healthy active lifestyle, but also a medium for maintaining and enhancing social relationships and stimulating and increasing sensitivity to mental, emotional, and character building aspects.
\end{abstract}

Keywords Sport Policy, Development, Government

\section{Introduction}

Sport has become an important aspect of government policy intervention, as evidenced by the number of countries articulating separate 'sports policies' with concurrent funding and support for elite and community sport development initiatives. The government considers sport an important aspect of economic and social activity for three reasons [1]. First, the sport has a strong cultural significance for most developed countries. Second, sport is considered a resource that can help achieve non-sporting goals. Third, sport is multidimensional, not only as a public service but also as an essential aspect of providing welfare and economic activity. Thus, sports can contribute in various ways to the achievement of government goals outside of sports policies that focus on the instrumental aspects of sports, such as increasing the performance of elite athletes and participation in sports.

In recent years, sport promotion and development have become an increasingly common feature of government sport policy and sport development-related activities in many countries [2]. Sustainable social development includes three accounts: the first is people, skills, and jobs; the second is sport legacy and culture; and the third is public health [3]. In South Korea, a 'sports development' approach focuses on elite development, organizational emphasis leading to nurturing talent that will encourage elite athletes [4]. In Spain, between 1975 and 1992, this was considered the 'golden age' of Sport for All. A decline in sport practice and new sport facility construction is thought to have occurred due to the introduction of new legal frameworks and variations in the budget allocated to sports [5]. In Japan, the focus of sport policy development 
began between 2007 and 2012 by enforcing new sport laws. Government policy was focused on the concept of a strong sport culture embodiment [6].

The sport development system has two main objectives: increasing the number of people actively involved in sports and improving sport achievement quality $[7,8]$. Sport is sometimes narrowly defined as a competitive and regulatory play, which involves multiple physical activity levels. The development gives rise to the notion of maturation, education, and consolidation of competencies, skills, and knowledge [9]. The power of exercise to provide benefits to participants has been a common message used for decades by sports proponents to promote physical activity and sports [10]. Various approaches have been made to study sport development, but the primary approach is sport development and development through sport. These two approaches differ in the objectives and expected results [4]. Coakley states that sport is a human creation and has different meanings from one place to another, and the purpose changes over time [11]. Thus, Indonesian perceptions on sport are different from Western concepts. In the specific term during the 1960s, sport means cultivation of body, which implies that the goal of the exercise is not only to get "men sana in copore sano" (a healthy mind in a healthy body) or to fulfill a need for recreation, but to achieve ideological goals [11]. The purpose of the research was to investigate the sport development policy in some countries by reviewing articles.

\section{Methods}

\section{Inclusion criteria}

A simple literature review was used for this research. A literature review method identifies, evaluates, and interprets all findings on a research topic to answer them [12]. The inclusion criteria of the study were as follows: 1 )
Sports development of each country, 2) observational studies.

\section{Database and search strategy}

Literature searches were limited to articles published from 2015-2019 in Elsevier and Taylor and Francis database. The research keywords were as follows: (sports development and sport policy and sport for all and participation in sports). All articles that passed the selection were reviewed and summarized based on their purpose, author's name, year of publication, number of respondents, instruments used, research results, and suggestions for further research.

\section{Selection of studies and data extraction}

The selection of the search strategy was involved, and all of the eligible articles were read fully. Several articles were extracted from each study: 1) authors identification, publication year; 2) method; 3) principal results.

\section{Results}

Nine articles were selected to be reviewed based on the selection criteria as shown in Table 1. The articles generally reported the development and the policies of sports in some countries. Sport policies are mostly directed to build character of the nation through the sport achievements, sports events, and sport involvement in the society. Each nation has imposed the laws regulating the implementation of sport activities, including the sport facilities, the financial support for sport events, and the management of sport organizations.

The findings from the review show that sport policies were developed based on the political and social conditions of the countries. This implies that the policies are strongly influenced by nation leaders and the political conditions of a country, including Indonesia. 
Table 1. The results of the literature review journal analysis

\begin{tabular}{|c|c|c|c|}
\hline Journal Title & Author & Year & Contents \\
\hline $\begin{array}{l}\text { Governmental Roles in Indonesian } \\
\text { Sport Policy: From Past to Present }\end{array}$ & Amung Ma'mun, (1) & 2019 & $\begin{array}{l}\text { The important role and support of the Indonesian government in } \\
\text { taking strategic steps in the development of sports based on the } \\
\text { law }\end{array}$ \\
\hline $\begin{array}{l}\text { Creating sport participation from } \\
\text { sport events: making it happen }\end{array}$ & $\begin{array}{l}\text { Laurence Chalipa, B. } \\
\text { Christine Greena, } \\
\text { Marijke Taksb and } \\
\text { Laura Misenerc (2) }\end{array}$ & 2016 & $\begin{array}{l}\text { Sport participation was claimed to be an advantage of elite } \\
\text { sporting events, but the facts did not support these claims. The } \\
\text { means to utilize the event to build participation had not been } \\
\text { developed. Some models were developed to build sport } \\
\text { participation. The model consisted of three elements: (1) the } \\
\text { cultural context of the sport, (2) the process of sports that exerts } \\
\text { influence on interests and (3)) the resources needed. This } \\
\text { research involved various methods by inviting } 12 \text { sport } \\
\text { development experts from Canada. }\end{array}$ \\
\hline $\begin{array}{l}\text { From Development of Sport to } \\
\text { Development through Sport: A } \\
\text { Paradigm Shift for Sport } \\
\text { Development in South Korea }\end{array}$ & $\begin{array}{l}\text { Jae-Pil Ha, Karam Lee } \\
\text { \& Gwang Ok (3) }\end{array}$ & 2015 & $\begin{array}{l}\text { The success of South Korea in building elite sports to become the } \\
\text { center of world sport power. However, South Korea had not paid } \\
\text { attention to the role of sport as a tool for social development. }\end{array}$ \\
\hline $\begin{array}{l}\text { Managing sport-for-development } \\
\text { and healthy lifestyles: The } \\
\text { sport-for-health model }\end{array}$ & $\begin{array}{l}\text { Nico Schulenkorf, Katja } \\
\text { Siefken (4) }\end{array}$ & 2018 & $\begin{array}{l}\text { The sport model for health as a flexible conceptual too } \\
\text { establishing the links between sport management, health } \\
\text { promotion, sociocultural development, policy, and sustainability } \\
\text { This model conceptually supported other SFD initiatives and, in } \\
\text { particular, health-related development projects in Vanuatu and } \\
\text { other Pacific regions }\end{array}$ \\
\hline $\begin{array}{l}\text { Sport-for-development: Inclusive, } \\
\text { reflexive, and meaningful research } \\
\text { in low- and middle-income settings }\end{array}$ & $\begin{array}{c}\text { Emma Sherry, Nico } \\
\text { Schulenkorf, Emma } \\
\text { Seal, Matthew } \\
\text { Nicholson Russell Hoye } \\
\text { (5) }\end{array}$ & 2016 & $\begin{array}{l}\text { The effectiveness of flexible, innovative and relevant research } \\
\text { designs providing support for inclusive, reflective, and } \\
\text { participatory research during the monitoring and evaluation } \\
\text { process resulting in a recommendation for a sports-based } \\
\text { development program. This research was conducted in Papua } \\
\text { New Guinea and five Pacific island countries. }\end{array}$ \\
\hline $\begin{array}{l}\text { Sport-for-All Policy in Taiwan: a } \\
\text { case of ongoing change? }\end{array}$ & $\begin{array}{l}\text { Ya-Wen Huang and } \\
\text { Tien-Chin Tan (6) }\end{array}$ & 2016 & $\begin{array}{l}\text { This study analyzed the extent to which sport policy changes for } \\
\text { all of Taiwan during the policy-making process and delivery of } \\
\text { the Sport Island Plan. Analysis showed that the Sports Island } \\
\text { Plan had not succeeded in overcoming a sports policy } \\
\text { shortcomings for all of Taiwan. It is suggested that future policy } \\
\text { should pay more attention to local sport organizations. }\end{array}$ \\
\hline $\begin{array}{l}\text { On sport for all and elitist sports in } \\
\text { Spain. Reply to David } \\
\text { Moscoso-Sanchez, Alvaro } \\
\text { Rodriguez-Diaz, and Jesus } \\
\text { Fernandez-Gavira } \\
\end{array}$ & Nuria Puig (7) & 2017 & $\begin{array}{l}\text { This study described the relationship between sport for all and } \\
\text { elite sport in Spain. Sport activities, especially elite athletes, are } \\
\text { organized democratically. }\end{array}$ \\
\hline $\begin{array}{l}\text { Sport for All in a financial crisis: } \\
\text { survival and adaptation in } \\
\text { competing for organizational } \\
\text { models of local authority sport } \\
\text { services }\end{array}$ & Neil King (8) & 2013 & $\begin{array}{l}\text { A strategy designed to increase exercise and physical activity } \\
\text { The study found that the competitive sports service organization } \\
\text { model in the UK largely determined the retention or restriction of } \\
\text { the Sports for All program. }\end{array}$ \\
\hline $\begin{array}{c}\text { Development of the sporting } \\
\text { nation: sport as a strategic area of } \\
\text { national policy in Japan }\end{array}$ & $\begin{array}{l}\text { Mayumi Ya-Ya } \\
\text { Yamamoto (9) }\end{array}$ & 2012 & $\begin{array}{l}\text { Changes in the sport policy of the Japanese government currently } \\
\text { revolved around developing development through sports to build } \\
\text { a country based on a strong sport culture. }\end{array}$ \\
\hline
\end{tabular}

\section{Discussion}

Sport and physical activities play an essential role in developing self-quality. Sport development is one of the efforts to strengthen the nation's existence in the international world [20]. The politicization of sports in Indonesia has had a strong effect on sports organizations in the country. In 1946, one year after the declaration of independence, the Indonesian Sports Association (PORI) was founded in Yogyakarta. PORI hosted the newly established National Sports Week (PON), an important nation-building tool in a young and internationally recognized country. The first PON took place in Surakarta in 1948 and aimed to create and demonstrate national unity. The Indonesian government's further aim was to gain international recognition. Participation in international sporting events, such as the Olympics or the newly established Asian Games, was a promising step towards achieving this target. After becoming a member of the United Nations in 1950, Indonesia participated in the First Asian Games in 1951 and prepared for the 1952 Olympics. In Helsinki's Olympics, the IOC welcomed Indonesia with the Indonesian Olympic Committee (Olympic Committee of the Republic of Indonesia, KORI, then changed into the Indonesian Olympic Committee, KOI) as a new member. In the 1950s, elite sports and competitions at the national 
and international levels became more widespread in Indonesia.

In Indonesia, sport is one of the tools in shaping character and identity. In addition, sports are also considered as a means of strengthening the view of the country to continue to exist globally. The vision of sport development under the Old Order's leadership was nationalism, and, from a contextual perspective, it was fundamental. It also shows great love and great pride, which the Indonesian people can rely on and exemplify [20].

A big concept is needed in carrying out development in Indonesia, with a large area consisting of 34 provinces, 524 districts/cities, and a population of approximately 250 million people, so it is necessary to have superior policies in carrying out the development process. Development must refer to the number of local governments and the existing population to be carried out sustainably according to their potential and needs, including development in the sport sector. Sport development must take into account the entire population to improve the quality of life. This kind of interpretation is very basic and must be in line with the essence of democracy, which creates leadership based on the majority of its trust. The leader must formulate superior and impartial policies based on realizing an advanced and cultured society quality of life.

The concept of sport development that should be developed to improve people quality of life as the locus for implementing democracy in the political system is by referring to the law. The sport development model that is being developed in Indonesia is the Triangle Model [20]. This triangle model elaborates the traditional model (Pyramid) and the house of sport (Geoff Cooke), which has been known and additional references from the UK actual model. The triangle model is directed to be a reference for leaders and decision-makers in seeing the direction of sport development following the sport scope. This model is considered ideal and rational because it can translate the legal umbrella of Law No. 3 Year 2005 concerning the National Sports System [21] and actual conditions or strategic issues of national sport development for both the medium and long term.

The triangle model perspective is a relatively simple idea that is expected to inspire policymakers, especially sport development policies. This thinking is named the triangle model perspective because it relies on three sports scopes developed in Law number 3 Year 2005 concerning the National Sports System, namely educational sports, recreational sports, and achievement sports. These three dimensions are built into a triangle shape. Each continuity of the three scopes inspires what to do to build progress in substance development, implementation strategy, and policy. It is now an indicator to see the progress of sport development achieved from a certain time to the next. This perspective was developed only to become a guiding start for leaders in the sports field who get a big role from the government. Their position is different when compared to sport development models developed by previous academics.

The second stage is sports activities developed to introduce the formal education environment through physical education and sports. The third stage is recreational sports activities that grow and develop as a tangible form of a healthy active lifestyle with facilitation and government regulation. The fourth stage is competitive sports activities aimed at achieving achievements, which are developed and created by sports clubs under the coordination of sports organizations. The models are developed and integrated into educational institutions. The fifth stage is developing superior sports through sport clubs, both amateur and professional. The sixth stage is the favorite sports, such as football, basketball, and volleyball, is facilitated by the private sector with business orientation and supported by the government and the development of the sports industry, which has become a lucrative phenomenon in the economic field. The seventh stage is the top sport as an optimal achievement in various multi-events and single-events that contributes to making the nation and state proud. The leading sport branch organizations directly carry out the coaching system. The government facilitates its financing. The implementation and coordination of its activities are assisted by the National Sports Committee, such as KONI and other sport committees. The House of Sport model has recently inspired the development of sport development models in some developed countries.

\section{Conclusion}

This review shows a shift in the concept paradigm from sport development to Sport for Development. Sports are not only to create a healthy and active lifestyle, but also as a medium for maintaining and enhancing social relationships and stimulating and increasing sensitivity to mental, emotional, and character building aspects. Even in some developed countries, sports can be used as a medium for political diplomacy. The sport industry is growing, thus the sport business becomes an interesting thing in advancing a nation's economy. The development of modern sport infrastructure shows that sport has become an icon for a country.

Sport development is an approach that views sport as a powerful engine to drive various development schemes that include the followings: 1) conflict resolution between groups (facilitating diplomacy in international relations), 2) human development (physical and psychological benefits), 3) promotion of cultural understanding, 4) infrastructure development (physical, social, and community), 5) health promotion and disease prevention, 6) empowerment (often about how sport can empower girls), 7) social integration 
and social capital development, 8) drivers of economic development (as seen through the national development strategies of some low-income countries aimed at encouraging increased foreign direct investment and sport tourism through, for example, hosting sporting events) [22].

The positive aspects of sport, emphasized by the United Nations in achieving development goals, are that efforts to use sport for peace and development can be replicated, effective, and practical. Sport is about participation, inclusion, and citizenship. In doing so, it brings individuals and communities together, highlights commonalities and bridges cultural and ethnic differences. Sport provides a forum for learning skills, such as discipline, self-confidence, and leadership, and teaches core principles, such as tolerance, cooperation, and respect [23].

In general, the management of sport development can be described as having three interrelated aspects: (a) normatively, sport development reflects various development goals; (b) analytically, sport development is concerned with managing the specific tasks involved in different interventions; and (c) the development of sport is process-oriented, continuous, changing, emerging, and influenced by communication, perception, behavior, and style issues, which need to be maintained, developed, or changed on an ongoing basis [24].

\section{REFERENCES}

[1] Hoye, Russell. Nicholson, Matthew. Houlihan B. Sport and Policy issues and analysis. 2010.

[2] Bloyce D. Sport Policy and Development. 2009. https://doi.org/10.4324/9780203890684.

[3] Levermore, Roger. Beacom A. Sport and International Development. 2008. https://doi.org/10.4324/97800805700 99.

[4] Ha J, Lee K, Ok G. The International Journal of the History of Sport From Development of Sport to Development through Sport : A Paradigm Shift for Sport Development in South Korea 2016;3367.https://doi.org/10.1080/09523367. 2015.1062756 .

[5] Puig N. On sport for all and elitist sports in Spain. Reply to David Moscoso-Sánchez, Álvaro Rodríguez-Díaz and Jesús Fernández-Gavira. Eur J Sport Soc 2017;0:1-13. https://doi.org/10.1080/16138171.2017.1374643.

[6] Coalter F. "There is loads of relationships here": Developing a programme theory for sport-for-change programmes. Int Rev Sociol Sport 2012:48(5) 594-612. https://doi.org/10.1177/1012690212446143.

[7] Green BC. Building Sport Programs to Optimize Athlete Recruitment, Retention, and Transition: Toward a Normative Theory of Sport Development 2005:233-53.

[8] Livingston LA, Forbes SL, Wattie N, Pearson N, Camacho
T, Varian P. Sport officiating recruitment, development, and retention: A call to action. Curr Issues Sport Sci 2017. https://doi.org/10.15203/ciss_2017.011.

[9] P. Bramham, K. Hylton JD and MN. SPORTS DEVELOPMENT Policy, process and practice. 2008.

[10] Reis AC, Carvalho M, Sousa-mast FR De. 'Sport for Development' in developing countries: The case of the Vilas Ol1' mpicas do Rio de Janeiro. Sport Manag Rev 2015:1-13. https://doi.org/10.1016/j.smr.2015.01.005.

[11] Lutan R. Indonesia and the Asian Games: Sport, nationalism and the "new order." Sport Soc 2005;8:414-24. https://doi.org/10.1080/17430430500249175.

[12] Wahyuningrum E. Parenting in Digital Era: a Systematic Literature Review. J Educ Heal Community Psychol 2020;9:226-58. https://doi.org/10.12928/jehcp.v9i3.16984.

[13] Ma'mun A. The International Journal of the History of Sport Governmental Roles in Indonesian Sport Policy: From Past to Present Governmental Roles in Indonesian Sport Policy: From Past to Present. Int J Hist Sport 2019;0:1-19. https://doi.org/10.1080/09523367.2019.1618 837.

[14] Chalip L, Green BC, Taks M, Misener L. Creating sport participation from sport events: making it happen. Int $\mathrm{J}$ Sport Policy 2017; 9: 257-76. https://doi.org/10.1080/1940 6940.2016 .1257496$.

[15] Schulenkorf N, Siefken K. Managing sport-for-development and healthy lifestyles: The sport-for-health model. Sport Manag Rev 2018:1-12. https://doi.org/10.1016/j.smr.2018.09.003.

[16] Sherry E, Schulenkorf N, Seal E, Nicholson M, Hoye R. Sport-for-development: Inclusive, reflexive, and meaningful research in low- and middle-income settings. Sport Manag Rev 2017;20:69-80. https://doi.org/10.1016/j .smr.2016.10.010.

[17] Huang Y, Tan T. Sport-for-All Policy in Taiwan : a case of ongoing change? 2016;0599. https://doi.org/10.1080/2164 0599.2015 .1051367$.

[18] King N. "Sport for All" in a financial crisis: Survival and adaptation in competing organisational models of local authority sport services. World Leis J 2013;55:215-28. https://doi.org/10.1080/04419057.2013.820503.

[19] Yamamoto MY. International Journal of Sport Policy Development of the sporting nation: sport as a strategic area of national policy in Japan. Int J Sport Policy Polit n.d.;4:2, 277-2. https://doi.org/10.1080/19406940.2012.68 5489 .

[20] Ma'mun A. PEMBANGUNAN OLAHRAGA NASIONAL (Konsep, Strategi dan Implementasi). 2017.

[21] Law of the Republic of Indonesia No. 3 of 2005 on National Sport System

[22] UN General Assembly. (2005). 2005 International Year for Sport and Physical Education Why Use Sports as a Tool for Peace and Development? Initiatives.

[23] Ha J, Lee K, Ok G. The International Journal of the History of Sport From Development of Sport to Development 
through Sport: A Paradigm Shift for Sport Development in South Korea 2016; 3367.https://doi.org/10.1080/09523367 .2015 .1062756
[24] Girginov, V. (2008). Sport and International Development. In Management of Sports Development. https://doi.org/10. 4324/9780080570099 